\title{
Smail Čekić, Vahid Karavelić, Nedžad Ajnadžić, Selmo Cikotić, Šefko Hodžić, Muhamed Smajić, Mesud Šadinlija, PRVI KORPUS ARMIJE REPUBLIKE BOSNE I HERCEGOVINE, Sarajevo 2017, 494 str.
}

Historiografija u Bosni i Hercegovini nije dosad ponudila puno temeljitih studija o događajima vezanim za raspad Jugoslavije i ratove koji su pratili taj proces. Većina radova o tome se ograničava na jednu perspektivu te zbog toga teško mogu izdržati ozbiljno kritičko preispitivanje. U tu grupu spada i većina radova koji se odnose na ratni put pojedinih vojnih formacija Armije Republike Bosne i Hercegovine.

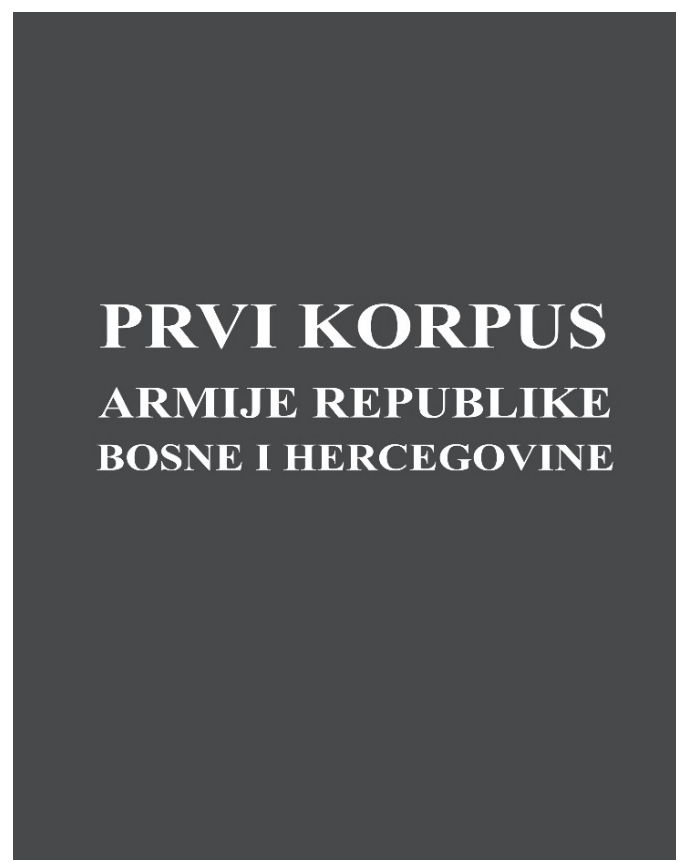

Nakon dužeg naučnoistraživačkog rada autorskog tima angažovanog na realizaciji naučnoistraživačkog projekta "Prvi korpus Armije Republike Bosne i Hercegovine“, čiji je nosilac bio Institut za istraživanje zločina protiv čovječnosti i međunarodnog prava Univerziteta u Sarajevu, a finansijsku podršku obezbijedilo Ministarstvo za boračka pitanja Kantona Sarajevo, pred naučnu, stručnu i najširu javnost 2017. godine izašla je iz štampe monografija Prvi korpus Armije Republike Bosne i Hercegovine. ${ }^{1}$

Knjiga autorskog tima: Smail Čekić, Vahid Karavelić, Nedžad Ajandžić, Selmo Cikotić, Šefko Hodžić, Muhamed Smajić i Mesud Šadinlija je historiografska studija o Prvom korpusu Armije Republike Bosne i Hercegovine (dalje: 1. korpus ARBiH) i predstavlja značajan doprinos za modernu historiografiju države Bosne i Hercegovine u cjelini.

1 U 2017. godini iz štampe je izašla i Monografija Drugi korpus Armije Republike Bosne i Hercegovine 1992-1995, Tuzla 2017, autora prof. dr. Seada Selimovića i prof. dr. Izeta Šabotića, univerzitetskih profesora sa Filozofskog fakulteta Univerziteta u Tuzli - Odsjek za historiju. 
Izdavač knjige je Institut za istraživanje zločina protiv čovječnosti i međunarodnog prava Univerziteta u Sarajevu. Recenzenti monografije su akademik prof. dr. Mirko Pejanović i prof. dr. Enver Imamović. Knjiga je štampana u tiražu od 1.000 primjeraka.

Monografija je strukturirana u deset poglavlja, uz odgovarajuće spiskove i registre.

Prvim poglavljem, pod naslovom Planiranje i pripremanje agresije na Republiku Bosnu i Hercegovinu i genocida nad Bošnjacima, prezentiran je pregled bitnih činjenica društveno-političkih procesa, kao općeg konteksta značajnih događaja kojima se predmetna monografija bavi. Predstavljena je suština i označeni akteri historijskih procesa, te data ocjena karaktera oružanog sukoba i priroda zločina u Republici Bosni i Hercegovini, s akcentom na planiranje, pripremanje, organizovanje i izvođenje agresije na Republiku Bosnu i Hercegovinu i izvršenje genocida nad Bošnjacima.

Poglavlje pod naslovom Početni period agresije, borbena dejstva $i$ organizacijsko-formacijski razvoj do formiranja 1. korpusa ARBiH sadrži vojnogeografske karakteristike prostora, demografsku strukturu stanovništva i političku strukturu vlasti sarajevske i goraždanske regije, te broj, sastav i strukturu elemenata oružanih snaga na ovom prostoru uoči agresije na Republiku Bosnu i Hercegovinu. Prezentirani su najvažniji događaji s početka agresije i objedinjavanje snaga odbrane, te opisana borbena dejstva do kraja augusta 1992. godine, uključujući pokušaje deblokade Sarajeva u okviru operacije "JUG-92".

Treće poglavlje, Formiranje 1. korpusa ARBiH, borbena dejstva $i$ organizacijsko-formacijski razvoj do kraja maja 1993, razmatra formiranje 1. korpusa i njime pokrenute organizacijsko-formacijske promjene; obrađuje borbena dejstva i operaciju Armije RBiH pod nazivom "KOVERTA“, čiji je nosilac 1. korpus, te izlaže opći razvoj prilika na bojištu i događaje u zoni odgovornosti 1 . korpusa do kraja maja 1993. godine.

Poglavlje Borbena dejstva i organizacijsko-formacijski razvoj 1. korpusa $u$ drugoj polovini 1993. razmatra kadrovske promjene na čelu Armije RBiH i organizacijsko-formacijske promjene inicirane početkom juna i detaljno opisuje tok borbenih dejstava u julu i augustu 1993. godine, koja su predstavljala presudnu odbranu Sarajeva pred agresorskim napadom u okviru ofanzive "LUKAVAC 93". U okviru ovog poglavlja prezentirane su i bitne činjenice o izgradnji Tunela D-B i učešću jedinica 1. korpusa u borbama u Hercegovini, kao i mjere preduzete u rješavanju problema s antidržavnim i kriminalnim elementima u vlastitim redovima. Poglavlje završava opisom borbenih dejstava na olovsko-vareškom i sarajevskom bojištu od novembra 1993. do februara 1994.

Peto poglavlje, pod naslovom Borbena dejstva i organizacijsko-formacijski razvoj 1. korpusa tokom 1994, izlaže pregled općeg razvoja prilika u zoni odgovornosti 1. korpusa i obimnih organizacijskih promjena izvršenih u ljeto 1994. godine, kao i prilagođavanje jedinica 1. korpusa bitno izmijenjenim uslovima na 
bojištu. U pregledu borbenih dejstava 1. korpusa od augusta do kraja 1994. godine opisani su najznačajniji ratni uspjesi 1 . korpusa na bjelašničko-treskavičkom i olovsko-vareškom bojištu.

U poglavlju Borbena dejstva i organizacijsko-formacijski razvoj 1. korpusa tokom 1995. daje se objašnjenje organizacijsko-formacijskih promjena nastalih formiranjem divizija u sastavu 1. korpusa i opis borbenih dejstava u proljeće 1995. godine. Središnje mjesto unutar poglavlja ima dio koji razmatra posljednju i najveću ofanzivu Armije RBiH izvedenu u namjeri deblokade Sarajeva, poznatu pod nazivom Operacija " $\mathrm{T}$ ". Nakon toga, prezentiran je opis borbenih dejstava u zoni odgovornosti 1. korpusa od okončanja Operacije "T" do kraja rata, te pregled angažovanja snaga 1. korpusa u završnim operacijama Armije RBiH u Bosanskoj krajini.

U poglavlju Jedinice 1. korpusa izložen je pregled nastanka i organizacijsko-formacijskog razvoja jedinica u sastavu 1. korpusa Armije Republike Bosne i Hercegovine. Pregled počinje od formacije s kojom je 1. korpus dočekao kraj rata u decembru 1995. godine i daje detaljan pregled nastanka, analizirajući stepene organizacijsko-formacijskog razvoja unazad, prema početku rata. Početno grupisanje, u pregledu je, shodno usvojenom pristupu: Komanda 1. korpusa i jedinice na njenoj direktnoj vezi, divizije u sastavu 1. korpusa, te na kraju sastav i struktura operativnih i taktičkih grupa, kao privremenih sastava, koji su u određenim periodima rata igrali značajnu ulogu u organizaciji i izvođenju borbenih dejstava 1. korpusa. Uz tekstualni dio opisa nastanka i razvoja pojedinih jedinica dati su i odgovarajući grafikoni koji vizuelno ilustruju opisane faze razvoja. Za svaku od jedinica navedeni su i podaci o broju odlikovanih pripadnika iz njenog sastava, te fotografije ratnih zastava i sačuvanih simbola i oznaka jedinica.

U osmom poglavlju, pod naslovom Struktura ljudstva i gubitaka u ljudstvu $i$ karakteristike rukovođenja i komandovanja u 1. korpusu ARBiH, iskazan je detaljan pregled brojnosti pripadnika 1. korpusa ARBiH po mjesecima i godinama (19921995), s analizom strukture pripadnika po različitim obilježjima. Identičan pristup primijenjen je i u analizi broja, sastava i strukture poginulih i ranjenih pripadnika 1. korpusa. U dijelu o aspektima rukovođenja i komandovanja u 1. korpusu tokom odbrambeno-oslobodilačkog rata 1992-1995. izvršena je analiza bitnih faktora nastanka, formiranja i djelovanja 1. korpusa $\mathrm{ARBiH}$, kao i generalna ocjena sistema rukovođenja i komandovanja.

U poglavlju Dobitnici odlikovanja i najvišeg ratnog priznanja u 1. korpusu $A R B i H$ prezentirana je, na osnovu dostupne arhivske građe i u saradnji s boračkim udruženjima ili $\mathrm{u}$ neposrednom kontaktu $\mathrm{s}$ odlikovanim pripadnicima, lista odlikovanih pripadnika i dobitnika ratnog priznanja "Zlatni ljiljan" iz sastava 1. korpusa.

Dostupna arhivska građa Arhiva ARBiH poslužila je kao osnova pripreme pregleda starješina po abecednom redu, koji su od 1992. do 1995. godine obavljali dužnosti u Komandi 1. korpusa, komandama divizija i operativnih grupa, kao 
i komandanata, zamjenika komandanata i načelnika štabova brigada i drugih jedinica na direktnoj vezi Komande 1. korpusa, koji sadrži poglavlje pod naslovom Starješine komandi i jedinica 1. korpusa.

Monografija sadrži i spisak korištenih izvora i literature, popis skraćenica i registre geografskih pojmova i ličnih imena.

Ova monografija svojim sadržajima i činjenicama svjedoči ne samo o slavnom ratnom putu 1. korpusa, kao složene jedinice Armije Republike Bosne i Hercegovine, već i o načinu na koji je jedan značajan dio države preživio sva iskušenja, teškoće i destrukcije izazvane agresijom na Republiku Bosnu i Hercegovinu.

Važno je naglasiti da je autorski tim na osnovu arhivske građe, onovremene štampe i relevantne literature, zauzimali se vrlo promišljene i objektivne stavove, što je ovom djelu dalo dodatnu vrijednost. U tom kontekstu nesumnjiva vrijednost ove knjige, je njena isprofilisanost i nedvojbenost u pogledu sagledavanja svih pozitivnih vrijednosti u tim teškim godinama. Bile su to godine surove borbe naroda ne samo za opstanak nego i za izgradnju svijesti o nacionalnom kontinuitetu i državnoj pripadnosti. Zbog toga je ova monografija postala simbolička, ali i neophodna dionica trnovitog puta kojim trebaju proći Bosna i Hercegovina i njeni narodi da bi prošlost postala svjedok vremena i primjer za pouku budućim generacijama.

S tim u vezi, može se reći da je knjiga Prvi korpus Armije Republike Bosne $i$ Hercegovine vrijedno naučno djelo, nasušno potrebno u ovo vrijeme, kada su javni diskursi i medijski prostor prepušteni različitim i često iskrivljenim tumačenjima i prepričavanjima događaja iz vremena agresije na Bosnu i Hercegovinu. Ona će razbiti brojne predrasude i pomoći da se prevaziđu jalova i neutemeljena polemiziranja, kako pojedinaca, tako i određenih grupa, oko pojma i karaktera odbrambeno-oslobodilačkog rata od 1992. do 1995. godine.

Zbog svega navedenog postoji potpuna opravdanost i svrsishodnost izlaženja ove knjige. Autorskom timu, uredništvu i izdavaču čestitam na ovoj knjizi, te je toplo preporučujem naučnoj, stručnoj i široj čitalačkoj javnosti. 